OPEN ACCESS

Edited by:

Hao Shen,

University of Pennsylvania, United States

Reviewed by:

Brian J. Akerley,

University of Mississippi Medical

Center, United States

$X$. Frank Yang,

Indiana University Bloomington,

United States

*Correspondence: Jon T. Skare

jskare@medicine.tamhsc.edu

Specialty section:

This article was submitted to

Microbial Immunology,

a section of the journal

Frontiers in Immunology

Received: 21 March 2018

Accepted: 18 April 2018

Published: 07 May 2018

Citation:

Zhi H, Xie J and Skare JT (2018) The Classical Complement Pathway Is

Required to Control Borrelia

burgdorferi Levels During

Experimental Infection.

Front. Immunol. 9:959.

doi: 10.3389/fimmu.2018.00959

\section{The Classical Complement Pathway Is Required to Control Borrelia burgdorferi Levels During Experimental Infection}

\author{
Hui Zhi, Jialei Xie and Jon T. Skare* \\ Department of Microbial Pathogenesis and Immunology, College of Medicine, Texas A\&M Health Science Center, Bryan, \\ $T X$, United States
}

Activation of the classical complement pathway occurs to varying degrees within strains of the Borrelia burgdorferi sensu lato complex, which contain a group of pathogenic spirochetes that cause tick-borne Lyme borreliosis, including the agent of Lyme disease in the United States, B. burgdorferi. Despite this information, details related to the control of $B$. burgdorferi by the classical pathway are not clear. To address this question, we infected $\mathrm{C} 1 \mathrm{q}^{-/-}$mice, which cannot assemble the C1 complex and thus fail to activate the classical pathway, with B. burgdorferi sensu stricto strain B31. Using bioluminescent in vivo imaging, we found that $\mathrm{C} 1 \mathrm{q}^{-/-}$mice harbored more $B$. burgdorferi following 10 days of infection relative to their isogenic C57BL/6 parent. Quantitative PCR (qPCR) demonstrated that $\mathrm{C} 1 \mathrm{q}^{-/-}$mice harbored significantly more $B$. burgdorferi than parent mice did within lymph nodes, skin, heart, and joints. The increased $B$. burgdorferi load in $\mathrm{C} 1 \mathrm{q}^{-/-}$mice was observed at 21 and 28 days of infection, consistent with the classical pathway promoting complement-dependent, antibody-mediated killing following the development of a $B$. burgdorferi-specific humoral immune response. In addition, circulating borrelial-specific IgM was higher in $\mathrm{C} 1 \mathrm{q}^{-/-}$mice relative to their parent mouse strain and did not decrease at 21 and 28 days post-infection, indicating that IgG class switching was delayed in $\mathrm{C} 1 \mathrm{q}^{-/-}$mice. At day 28 , both Borrelia-specific $\lg \mathrm{G} 1$ and IgG3 levels were higher in infected $\mathrm{C} 1 \mathrm{q} \alpha^{-/-}$mice, but that these antibodies were not sufficient to control borrelial infection in the absence of the classical pathway. Furthermore, the lack of $\mathrm{C} 1 \mathrm{q}$ also altered the balance of the Th1/Th2 response, as both circulating Th1 (MIP-1 $\alpha, \mathrm{IL}-2, \mathrm{IL}-12$, and TNF $\alpha$ ), Th2 (IL-4, IL-10, and MCP-1), and Th17 (IL-17) cytokines were elevated in infected $\mathrm{C} 1 \mathrm{q} \alpha^{-/-}$mice. These data imply that $\mathrm{C} 1 \mathrm{q}$ and the classical pathway play important roles in controlling borrelial infection via antibody and complement-dependent killing, as well as altering both antibody maturation processes and the T cell response following exposure to infectious $B$. burgdorferi.

Keywords: spirochetes, Borrelia burgdorferi, complement system proteins, innate immunity, C1q

\section{INTRODUCTION}

Lyme disease is associated with infection following exposure to spirochetal bacteria of the Borrelia burgdorferi sensu lato complex, which is predominantly defined by B. burgdorferi sensu stricto (referred to as B. burgdorferi herein), Borrelia afzelii, and Borrelia garinii. These Borrelia species are all transmitted to human hosts through the bite of an infected tick. In the 
United States, B. burgdorferi is the leading tick-borne infection with approximately 300,000 diagnosed cases each year (1). Following infection, B. burgdorferi disseminates to distant organs including joints, heart, and the central nervous system (2-5). In the absence of antibiotic treatment, B. burgdorferi infection may lead to significant morbidity that may manifest in the form of carditis, arthritis, or neurologic pathologies. During the infectious process, $B$. burgdorferi avoids clearance via the innate immune system that includes complement-mediated killing. Despite this inherent resistance to innate immune mechanisms, there is much that is unknown regarding how B. burgdorferi persists in the face of a potent innate and adaptive immune response.

The complement system is a proteolytic cascade that interfaces with both the innate and adaptive immune responses (6-9). Following infection, the complement system can be activated by three different pathways, defined as the classical, lectin, and alternative pathways (APs), via the recognition of distinct microbial molecular patterns. The classical pathway is activated by the recognition of either antigen-antibody immune complexes or antibody-independent ligands via the globular head of C1q, while glycol ligands activate the lectin pathways. The AP is activated when surface attached $\mathrm{C} 3 \mathrm{~b}$ interacts with the protease factor $B(\mathrm{fB})$ and $\mathrm{D}(\mathrm{fD})$, which results in the formation of the AP C3 convertase C3bBb (10). The AP depends on low level, yet continuous, $\mathrm{C} 3 \mathrm{~b}$ deposition by soluble $\mathrm{C} 3\left(\mathrm{H}_{2} \mathrm{O}\right) \mathrm{Bb}$ convertases that occur from interactions of $\mathrm{fB}$ and $\mathrm{fD}$ with spontaneously hydrolyzed C3 "tick-over" (11). Then, AP C3 convertases amplify $\mathrm{C} 3$ conversion on the target surface as $\mathrm{C} 3 \mathrm{~b}$ serves the scaffold for assembly of new C3bBb convertases (12). All three pathways converge at the cleavage of complement component $\mathrm{C} 3$ into the anaphylatoxin $\mathrm{C} 3 \mathrm{a}$ and opsonic $\mathrm{C} 3 \mathrm{~b}$ fragment, with the latter deposited on the microbial surface resulting in the formation of the membrane attacking complex required to lyse the cell.

Activation of the classical pathway is well known for mediating antibody-dependent clearance of microbes as C1q, together with $\mathrm{C} 1 \mathrm{r}$ and $\mathrm{C} 1 \mathrm{~s}$, recognizes and binds to antigen-antibody complexes with high affinity to activate the complement cascade, resulting in the formation of the membrane attack complex (MAC) and the killing of the invading organisms (13). As a part of $\mathrm{C} 1$, the classical complement pathway initiation complex $\mathrm{ClqC}_{1} \mathrm{r}_{2} \mathrm{Cls}_{2}, \mathrm{Clq}$ recognizes multiple $\mathrm{Fc}$ regions of $\operatorname{IgM}$ or IgG within the immune complex and enables auto-activation of the serine protease $\mathrm{C} 1 \mathrm{r}$, which leads to the cleavage of serine protease $\mathrm{C} 1 \mathrm{~s}$. Activated $\mathrm{C} 1 \mathrm{~s}$ then cleaves $\mathrm{C} 4$ and $\mathrm{C} 2$ to generate the classical complement convertase $\mathrm{C} 4 \mathrm{~b} 2 \mathrm{~b}$ and the $\mathrm{C} 5$ convertase $\mathrm{C} 4 \mathrm{~b} 2 \mathrm{~b} 3 \mathrm{~b}$, which promotes the formation of the MAC that mediates antibody-dependent killing. Within this process, the chemotactic peptides C3a and $\mathrm{C} 5 \mathrm{a}$ are released to recruit immune effector cells to the site of infection and opsonize the pathogen through $\mathrm{C} 3 \mathrm{~b}, \mathrm{iC} 3 \mathrm{~b}, \mathrm{C} 1 \mathrm{q}$, and C4b (14).

In addition to its role in antigen-antibody recognition, various roles of $\mathrm{Clq}$ independent of complement activation have been observed in regulating both the innate and adaptive immune response. In the absence of $\mathrm{C} 1 \mathrm{r}$ and $\mathrm{C} 1 \mathrm{~s}$, immobilized $\mathrm{C} 1 \mathrm{q}$ enhanced $\mathrm{Fc} \gamma \mathrm{R}$-mediated phagocytosis, when targets were coated with a sub-optimal concentration of antibody (15). These data suggest that C1q may aid clearance independent of antibody production in the early stages of the humoral immune response or, alternatively, in immunocompromised hosts with limited antibody production (14). C1q also decreases proinflammatory cytokine production and promotes the release of anti-inflammatory cytokines in macrophages, dendritic cells, and microglia, consistent with its role in the clearance of cell debris (16). In this case, C1q bound apoptotic cells are ingested by human macrophages resulting in the secretion of IL-10 and IL-27, thereby creating a less inflammatory state (17). The resulting C1q-coated apoptotic cells substantially decrease Th1 and Th17 subset proliferation and stimulate Treg proliferation, suggesting that this anti-inflammatory function of $\mathrm{C1q}$ skews the adaptive immune response toward a more regulatory state (18). These complement activation-independent functions of $\mathrm{C} 1 \mathrm{q}$ may affect $B$. burgdorferi infection by regulating these different aspects of the immune response that contribute to the pathology observed. Interestingly, it has been shown that antigen-specific antibody production is delayed during borrelial infection (19). This could then result in insufficient $\mathrm{C} 4 \mathrm{~b}$ deposition on follicular dendritic cells following borrelial infection, leading to the premature collapse of germinal center and diminished antigen presentation by the follicular dendritic cells to B cells within the germinal center (20). These studies, as well as others, make it clear that, in addition to antigen-antibody recognition and classical complement activation with subsequent killing, there are additional functions associated with $\mathrm{Clq}$ that may be important in the host response against foreign invaders (14).

Borrelia burgdorferi sensu lato isolates vary in their abilities to avoid complement killing. For example, B. afzelii strain Pko and $B$. burgdorferi strain B31 are resistant to complementdependent killing in normal human serum, while some $B$. garinii strains are sensitive to $\mathrm{C} 1 \mathrm{q}$-mediated complement killing in vitro since the depletion of C1q eliminated killing (21). These observations suggest that serum-resistant strains of Borrelia have evolved to avoid complement-dependent killing, including those associated with the classical pathway. Indeed, direct inhibitors of the classical pathway have recently been discovered in B. burgdorferi and include surface lipoproteins BBK32 and OspC $(22,23)$. While BBK32 recognizes the initiator protease $\mathrm{C} 1 \mathrm{r}$ and inhibits its proteolytic activity, OspC binds to the complement component $\mathrm{C} 4 \mathrm{~b}$ and restricts killing via the classical and lectin pathways $(22,23)$.

Despite extensive in vitro studies, the function of the complement system in controlling borrelial infection in vivo remains unresolved, particularly in regard to the classical pathway. In this study, we compared the infectivity of wild-type $B$. burgdorferi $\mathrm{B} 31$ derivative strain in $\mathrm{C} 57 \mathrm{BL} / 6$ and isogenic $\mathrm{C} 1 \mathrm{q}^{-/-}$mice that are unable to activate the classical pathway to determine how the classical complement pathway affects B. burgdorferi infection. By using in vivo imaging and quantitative PCR (qPCR), along with multiplex analysis, we found that $\mathrm{C} 1 \mathrm{q}$ plays an important role in limiting $B$. burgdorferi levels in different tissues following infection, and also affects the regulation of both cytokine and immunoglobulin production that are presumed to limit borrelial burden and resolve localized inflammation. 


\section{MATERIALS AND METHODS}

\section{Bacterial Strains}

Borrelia burgdorferi B31 MSK5 and ML23/pBBE22luc (24, 25) were grown in BSK-II media supplemented with $6 \%$ normal rabbit serum (Pel-Freez Biologicals, Rogers, AR, USA). B. burgdorferi cultures were grown at $32^{\circ} \mathrm{C}, 1 \% \mathrm{CO}_{2}, \mathrm{pH} 7.6$. ML23/pBBE22luc was grown with kanamycin at $300 \mu \mathrm{g} \mathrm{ml}^{-1}$ to provide selective pressure to maintain pBBE22luc. The use of infectious B. burgdorferi in this study was reviewed and approved by the Institutional Biosafety Committee at Texas A\&M University.

\section{Mouse Strains}

C57BL/6 parent mice were obtained from Charles Rivers. C1q $\alpha$ knockout mice [in the C57BL/6 background (26)] were kindly provided by $\mathrm{Dr}$. Yi Xu, Texas A\&M Institute for Biosciences and Technology, Houston, TX, USA. The C1q $\alpha^{-/-}$mice were bred within the Texas A\&M University Health Science Center vivarium facility.

\section{Infectivity Studies and Bioluminescent Imaging}

Infectivity studies were performed as previously described (27). Briefly, 8- to 10-week-old C57BL/6 (parent) and C1q $\alpha^{-1-}$ mice were inoculated intradermally with $10^{4}$ of either B. burgdorferi strains MSK5 or ML23/pBBE22luc. For each dose and strain used, four to five mice were infected. Imaging of infected mice to detect bioluminescent B. burgdorferi (e.g., ML23/pBBE22luc) was done as previously described (25). After 10, 21, and 28 days, the mice were sacrificed and inguinal lymph node (LN), skin, heart, spleen, bladder, and tibiotarsal joint tissues were aseptically collected for in vitro cultivation and for $\mathrm{qPCR}$ analysis to quantify B. burgdorferi burden as described $(25,28)$. All animal experiments were performed in accordance to the Association for Assessment and Accreditation of Laboratory Animal Care guidelines. The Texas A\&M University Institutional Animal Care and Use Committee reviewed and approved all animal procedures used in this study.

\section{DNA Extraction of $B$. burgdorferi from Infected Tissues and qPCR Analysis}

Total DNA was isolated from mice skin, LN, heart, and tibiotarsal joint samples using the Roche High Pure PCR template preparation kit as previously described (28). Approximately $100 \mathrm{ng}$ of total DNA was used for each qPCR reaction. Quantitative PCR analysis was conducted using the Applied Biosystems ABI 7900 HT system. B. burgdorferi genome copies and mammalian cell equivalents were determined using either the oligonucleotides nTM17FRecA (5'-GTGGATCTATTGTATTAGATGAGGCT-3') and nTM17RRecA (5'-GCCAAAGTTCTGCAACATTAACA CCT-3') $(28,29)$, and primer set beta-actin-F (5'-AGAGGGA AATCGTGCGTGAC-3') and beta-actin-R (5'-CAATAGTGAT GACCTGGCCGT-3') (30), respectively. The bacterial burden was depicted as the number of B. burgdorferi recA copies per $10^{6}$ beta-actin copies.

\section{Serum Collection and Multiplex Cytokine Profiling}

Blood was collected by cardiac puncture in endotoxin-free tubes with no additive. The blood samples were allowed to clot at room temperature for $30 \mathrm{~min}$ before centrifugation $(400 \times g$, $4^{\circ} \mathrm{C}, 10 \mathrm{~min}$ ) and the serum was collected and stored at $-80^{\circ} \mathrm{C}$ until use.

Serum cytokine levels were measured by using the Luminex 200 multiplex assay (Bio-Rad, Hercules, CA, USA), according to the manufacturer's protocol, with a customized MilliplexMap mouse cytokine/chemokine magnetic bead panel (Millipore). Briefly, serum samples were diluted 1:2 with assay buffer, and $25 \mu \mathrm{l}$ of bead working solution was added to each well containing either the diluted serum samples or a standard, followed by incubation overnight at $4^{\circ} \mathrm{C}$ with agitation. The next day, the plate was washed twice with $200 \mu \mathrm{l}$ of wash buffer, $25 \mu$ lof detection antibody cocktail were then added to each well, and the samples incubated at room temperature for $1 \mathrm{~h}$ with agitation. Subsequently $25 \mu \mathrm{l}$ of streptavidin-phycoerythrin was added to each well and incubated at room temperature for $30 \mathrm{~min}$. Following an additional two washes, $150 \mu$ l of sheath fluid was added to each well. Sample data were then analyzed and calculated based on a standard curve of each analytes using the Bio-Plex Manager software. Analytes measured included IL-2, IL-4, IL-6, IL-10, IL-12, IL-17, TNF- $\alpha$, keratinocyte-derived chemokine (KC), monocyte chemoattractant protein (MCP-1/CCL2), and macrophage inflammatory protein (MIP-1 $\alpha /$ CCL3).

\section{Total Immunoglobulin Profiling}

Serum samples were collected as mentioned earlier. Total serum immunoglobulin concentration of IgA, IgG1, IgG2a, IgG2b, IgG3, and IgM were determined using the Luminex 200 multiplex assay (Bio-Rad, Hercules, CA, USA), using a mouse immunoglobulin isotyping panel (Millipore) according to the manufacturer's suggested protocol.

\section{Borrelia-Specific Immunoglobulin Profiling}

Serum was assayed using an ELISA to quantify B. burgdorferispecific antibody production using the mouse Type Isotyping kit (Bio-Rad). To conduct this assay, 96-well microtiter plates were coated with sonicated B. burgdorferi strain B31 at $5 \mu \mathrm{g} / \mathrm{ml}$ in carbonate buffer ( $\mathrm{pH}$ 9.3), and one empty column (with no antigen) on each plate was reserved for serial dilution of purified mouse IgG1, IgG2a, IgG2b, IgG3, or IgM (eBioscience) to generate a standard curve. The plate was then blocked with $1 \%$ BSA for $1 \mathrm{~h}$ at room temperature. After a brief wash in PBS/ $0.2 \%$ Tween-20, serial dilutions of serum samples were added to the sonicate-coated wells and incubated for $1 \mathrm{~h}$ at room temperature. Following six washes in PBS/0.2\% Tween-20, rabbit anti-mouse IgG1, IgG2a, IgG2b, IgG3, or IgM (Bio-Rad) was added to each well (as appropriate) and incubated for $1 \mathrm{~h}$. Each well was then washed six times in PBS/0.2\% Tween-20 and then incubated in PBS/0.2\% Tween-20 containing a 1:3,000 dilution of horseradish peroxidase conjugated anti-rabbit IgG for $1 \mathrm{~h}$. The wells were then washed in PBS/0.2\% Tween-20, after which 3,3',5,5'-tetramethylbenzidine was added as substrate. The enzymatic reaction was stopped after 
1 min using $0.16 \mathrm{M}$ sulfuric acid (Thermo Scientific), and the absorbance at $450 \mathrm{~nm}$ was determined. Ig content was measured by comparison to the standard curve generated from serially diluted purified Ig on individual plates.

\section{Data and Statistical Analysis}

For qPCR analysis, a one-tailed Mann-Whitney's $t$-test was performed between the mouse strains indicated. For the bioluminescent samples, two-way analyses of variance were performed among variables, and Bonferroni method was used to correct $P$-values for multiple comparisons. Multiple $t$-test was performed for both the cytokine and immunoglobulin profiling analyses, and the Sidak-Bonferroni method was used to correct $P$-values for multiple comparisons. Statistical significance was accepted when the $P$-values were less than 0.05 for all statistical analyses employed.

\section{RESULTS}

\section{C1q Is Required to Manage B. burgdorferi Infection}

To determine the role of the classical complement pathway in B. burgdorferi infection, we inoculated $\mathrm{C} 1 \mathrm{q}^{-/-}$and the isogenic parent $\mathrm{C} 57 \mathrm{BL} / 6$ mice with $10^{4}$ cells of infectious B. burgdorferi strain B31. Borrelial burden was determined by quantitative PCR (qPCR) from skin, LN, tibiotarsal joint, and heart from C57BL/6 and $\mathrm{C} 1 \mathrm{q}$ knockout mice at 21 and 28 days post-infection. At day 21, $\mathrm{C} 1 \mathrm{q}^{-/-}$mice exhibited significantly higher bacterial load in the skin, joint, and heart, when compared with the C57BL/6 parent mice (Figure 1A). On day 28, the absolute numbers of B. burgdorferi were somewhat lower than that seen in the same tissues as day 21 , regardless of the $\mathrm{C1q}$ content in the mice, most likely due to the borrelial-specific antibody killing that helps to limit the infection (Figure 1B). However, $\mathrm{C} 1 \mathrm{q}^{-/-}$mice still harbored sevenfold to ninefold higher $B$. burgdorferi burden in both joint and heart tissues relative to C57BL/6 mice (Figure 1B). Taken together, these data suggest that the classical complement pathway controls systemic colonization of B. burgdorferi. This result is consistent with the role of classical complement function in the selective antibody-mediated killing of B. burgdorferi.

\section{The Classical Complement Pathway Limits B. burgdorferi Dissemination in Mice}

Next, we asked if the classical complement pathway controls $B$. burgdorferi infection at early stage of infection before borrelialspecific IgG develops, by tracking the active infection using in vivo imaging. To this end, we infected the $\mathrm{C} 57 \mathrm{BL} / 6$ parent and $\mathrm{C} 1 \mathrm{q}^{-/-}$mice with a B31 derivative strain containing borrelial codon-optimized firefly luciferase (ML23/pBBE22luc) (25) at dose of $10^{4}$ cells and measured light emission from the live bacteria following exposure to D-luciferin substrate. At early time points, e.g., $1 \mathrm{~h}, 1,4$, and 7 days post-infection, C57BL/6 and $\mathrm{C} 1 \mathrm{q} \alpha^{-1-}$ mice demonstrated equivalent light emission from skin tissue (data not shown), suggesting that C1q does not alter the innate immune response to control borrelial replication and colonization. At day 7, the light signal peaked in C57BL/6 mice and started to decline at day 10 , suggesting the bacterial load had peaked following 1 week of infection. In $\mathrm{C} 1 \mathrm{q}^{-/-}$mice, $B$. burgdorferi levels reached their maximum intensity at day 10 (Figure 2A) at a level that was approximately fourfold higher than signal detected in C57BL/6 mice when all detectable light from each mouse is compared (Figure 2B). Light emission from the joint area was also approximately twofold higher in $\mathrm{C} 1 \mathrm{q} \alpha^{-/-}$ mice than relative to the $\mathrm{C} 57 \mathrm{BL} / 6$ parent at day 10 of infection (Figure 2C). It is important to note that we cannot rule out the possibility that light emission from joints at day 10 was partially due to signal originating from the overlying skin. It is likely that the classical pathway is activated by antigen-specific IgM
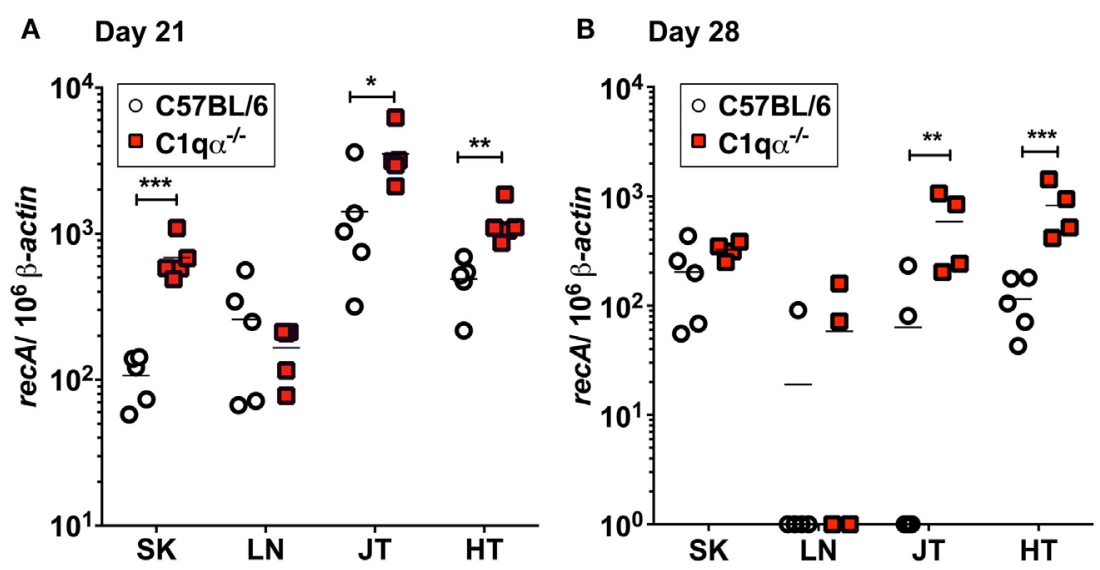

FIGURE 1 | Quantitative PCR of infectious Borrelia burgdorferi in the parent C57BL/6 mice versus mice lacking the complement protein C1q (C1q $\alpha^{-/-}$). Mice were infected with $10^{4}$ B. burgdorferi strain MSK5 (24) for (A) 21 days and (B) 28 days and total DNA isolated from skin (SK), lymph node (LN), joints (JT), and heart (HT). The white circles refer to the parent C57BL/6 mouse background samples whereas the red squares indicate the values determined from the $\mathrm{C} 1$ q $\alpha^{-/-}$knockout mouse tissues samples ( $n=4$ or 5 ). The results are represented as the number of borrelial genome copies per $10^{6}$ mouse $\beta$-actin copies $\left({ }^{\star} P<0.05\right.$; ${ }^{\star \star} P<0.01$; and $\left.{ }^{* \star *} P<0.001\right)$ 

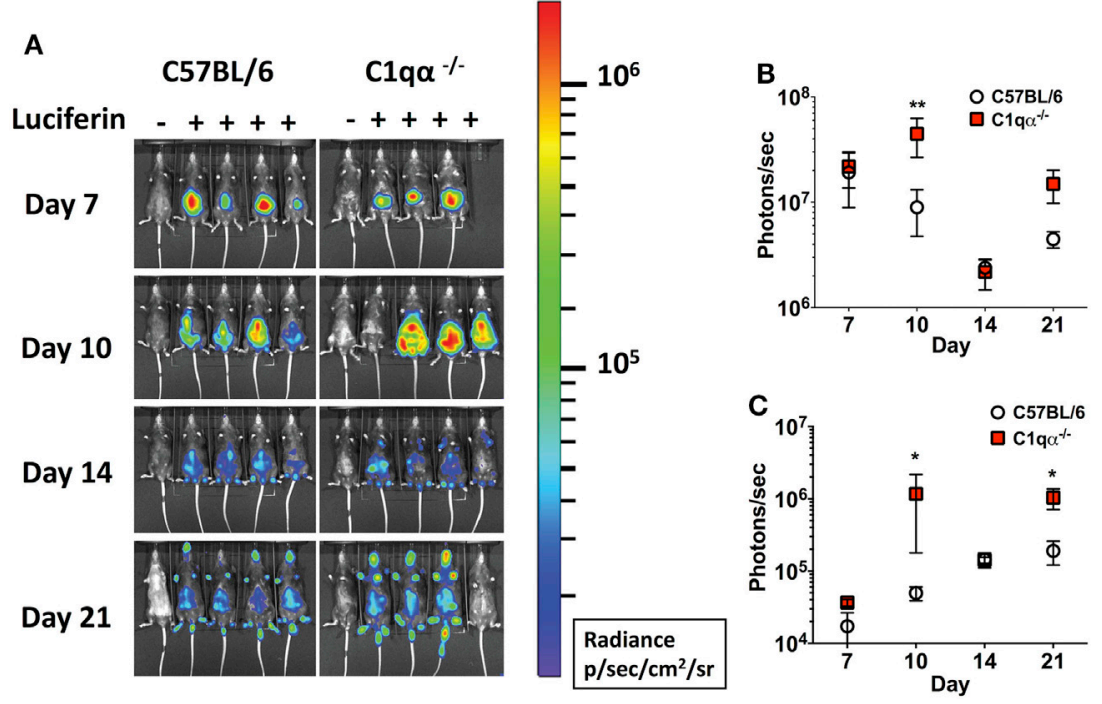

FIGURE 2 | Temporal and spatial tracking of Borrelia burgdorferi strains following infection in C1q $\alpha^{-/-}$mice. (A) C57BL/6 and C1q $\alpha^{-/-}$mice were infected with B. burgdorferi containing firefly luciferase at a dose of $10^{4}$. Mice were treated with D-luciferin at $7,10,14$, and 21 days post-infection and imaged. For each image shown, the mouse on the far left was infected with B. burgdorferi but did not receive D-luciferin serves as a background control. The image shown was obtained from a 10 min exposure. All images from each time point were normalized to the same photon/second (p/s) range of $1.15 \times 10^{4}$ to $1.86 \times 10^{6}$ and displayed on the same color spectrum scale (right). (B) Quantification of in vivo luminescence from each mouse. Total detected light was measured for each individual mouse in its entirety, and the total flux value was determined (in photons/second). The total flux values from mice treated with $\mathrm{D}$-luciferin were normalized by subtracting the background total flux value of the infected mouse with no added luciferin relative to mice that were given luciferin. Total flux was determined after infection at days 7, 10, 14, and 21 for mice infected with $10^{4}$ B. burgdorferi. (C) Quantification of in vivo luminescence from the joint region. The joint localized signal was selectively measured, and the total flux value was determined (in photons/second). Each data point represents the average signal from the left and right ankles of each mouse. White circles and red squares represent signal from C57BL/6 and C1q $\alpha^{-/-}$mice, respectively, both infected with $\mathrm{ML} 23 / \mathrm{pBBE} 22 / \mathrm{lc}$ ( $n=3$ or 4; ${ }^{\star} P<0.05$ and ${ }^{\star \star} P<0.01$ ).

at day 10 and kills B. burgdorferi in an IgM-dependent manner. Interestingly, although the colonization of B. burgdorferi in both $\mathrm{C} 57 \mathrm{BL} / 6$ and $\mathrm{C} 1 \mathrm{q}^{-/-}$mice decreased to a similar level at day 14 , light emission is almost fivefold higher at day 21 in the joints of all $\mathrm{C} 1 \mathrm{q}^{-/-}$mice relative to the joints of the C57BL/6 parent mice (Figure 2C), suggesting that the classical complement pathway controls B. burgdorferi levels at secondary colonization sites. Another possibility is that antibody-independent C1q-mediated opsonization occurs via macrophages that clear B. burgdorferi (31). Given that there is little difference observed in clearance before day 10 for the parent or C1q $\alpha^{-/-}$mice, it seems less likely that the differences observed are due to macrophage clearance but instead are the result of $\mathrm{C1q}$-mediated antibody-dependent killing either via MAC formation or delayed opsonization by neutrophils following the development of B. burgdorferi-specific antibodies (31).

\section{C1q-Deficient Mice Accumulate Significantly Higher B. burgdorferi Following Dissemination}

To quantify $B$. burgdorferi colonization in deeper tissues of $\mathrm{C} 57 \mathrm{BL} / 6$ and $\mathrm{C} 1 \mathrm{q}^{-/-}$infected mice at an earlier time point, quantitative PCR (qPCR) was performed to enumerate spirochete levels in skin, LN, tibiotarsal joint, and heart at day 10 relative to 21 days post-infection. At day 10, more bacteria were recovered from the skin of $\mathrm{C} 1 \mathrm{q} \alpha^{-/-}$mice than the C57BL/6 parent (Figure 3A); however, the differences observed were not statistically significant due to the large variation seen in the C57BL/6 mice. These data are consistent with the in vivo imaging result on day 10 (Figure 2A). In contrast to skin samples, B. burgdorferi was present at low levels in LNs, joint, and heart tissues (Figure 3A), suggesting that B. burgdorferi had poorly colonized these sites at day 10 . At day 21, a higher B. burgdorferi load was detected from all tested tissues from $\mathrm{C} 1 \mathrm{q}^{-/-}$mice relative to the C57BL/6 parent (Figure 3B), a result that is consistent with the increased borrelial load for MSK5 in Figure 1A and the higher light signal observed for the luciferase-producing B. burgdorferi (Figure 2).

\section{Absence of C1q Alters Cytokine/ Chemokine Levels in Response to $B$. burgdorferi Infection}

In addition to its role in the classical complement pathway, $\mathrm{Clq}$ also affects the inflammatory response following and concurrent with infections and tissue damage $(32,33)$. To determine if the absence of $\mathrm{C} 1 \mathrm{q}$ alters the inflammatory response following B. burgdorferi infection, we measured the levels IL-2, IL-4, IL-10, IL-12p70, IL-17, KC, MCP-1, MIP-1 $\alpha$, TNF $\alpha$, and VEGF in sera derived from $\mathrm{C} 57 \mathrm{BL} / 6$ parent and $\mathrm{C} 1 \mathrm{q}^{-/-}$mice infected with B. burgdorferi at $7,10,21$, and 28 days post-infection. None of 

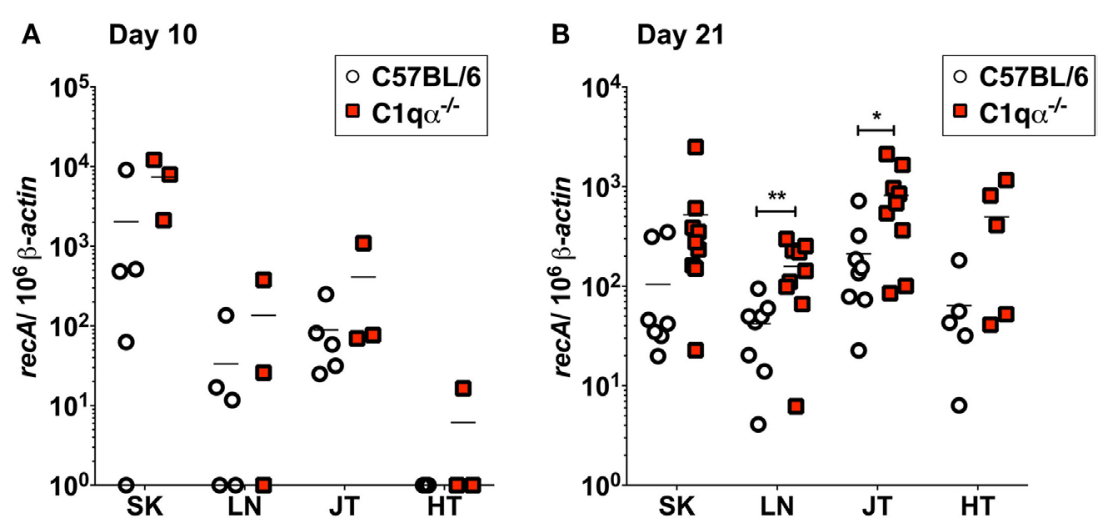

FIGURE 3 | Bacterial load of Borrelia burgdorferi in C57BL/6 and C1q $\alpha^{-/-}$mice. Quantitative PCR (qPCR) from mice infected with 104 B. burgdorferi strain (ML23/ pBBE22/uc) following 10 days (A) or 21 days (B). White circles and red squares indicate the data points from samples of C57BL/6 and C1 q $\alpha^{-/-} \mathrm{knockout} \mathrm{mice,}$ respectively $[n=3-4$ for panel $(\mathbf{A}) ; n=9$ for panel $\mathbf{( B )}]$. Abbreviations: SK, skin; LN, lymph node; JT, joints; HT, heart. The results are represented as the number of borrelial genome copies per $10^{6}$ mouse $\beta$-actin copies ( ${ }^{\star} P<0.05$ and ${ }^{\star \star} P<0.01$ ).

the cytokines tested showed significant different level of production between $\mathrm{C} 57 \mathrm{BL} / 6$ and $\mathrm{C} 1 \mathrm{q} \alpha^{-/-}$mice at days 7,10 , and 21 (Figure 4). However, at day 28, levels of IL-2, IL-4, IL-10, IL-12, IL-17, MCP-1, MIP-1 $\alpha$, and TNF $\alpha$ were significantly higher in $\mathrm{C} 1 \mathrm{q}^{-/-}$relative to the $\mathrm{C} 57 \mathrm{BL} / 6$ parent mice (Figure 4). More specifically, IL-2, IL-10, IL-12, and IL-17 increased approximately threefold, while IL-4, MCP-1, and MIP-1 $\alpha$ increased twofold in mice lacking $\mathrm{C} 1 \mathrm{q}$ (Figure 4). This result indicates that $\mathrm{C1q}$ affects the regulation and/or balance of the Th1 (MIP-1 $\alpha$, IL-2, IL-12, and TNF $\alpha$ ), Th2 (IL-4, IL-10, and MCP-1), and Th17 (IL-17) responses to $B$. burgdorferi infection. However, the imbalance of $\mathrm{T}$ cell response observed in $\mathrm{C} 1 \mathrm{q}^{-/-}$mice was restricted in $B$. burgdorferi-infected mice, as cytokine response was not observed in the mock-infected $\mathrm{C} 57 \mathrm{BL} / 6$ parent or $\mathrm{C} 1 \mathrm{q} \alpha^{-/-}$mice (data not shown).

\section{Lack of C1q Alters Immunoglobulin Subtype Population During Borrelial Infection}

The importance of antibody production in the control of B. burgdorferi infection has been well addressed both in vitro and in vivo. Previous studies have shown that $B$. burgdorferi-specific IgG in polyclonal antisera from experimentally infected mice and from humans with Lyme disease, as well as selected monoclonal IgG produced from infected mice, can prevent colonization in mice, but are incapable of eliminating $B$. burgdorferi from previously infected mice (34-38).

To determine if the lack of the classical complement pathway affects antibody development during borrelial infection, we measured the levels of each subtype of total immunoglobulins using a multiplex approach, and B. burgdorferi-specific immunoglobulins IgA, IgG, and IgM in sera from C57BL/6 and C1 $\mathrm{q}^{-/-}$mice infected with B. burgdorferi using an ELISA based assay (Figures 5A-F). The results showed that the total amount of IgG2a are lower in $\mathrm{C} 1 \mathrm{q}^{-/-}$mice before day 10 (Figure 5C). At day 21 post-infection, IgG2b level is significantly lower in $\mathrm{Clq}^{-/-}$mice relative to
C57BL/6 mice (Figure 5D). C1q $\alpha^{-/-}$mice showed marginally higher production of IgM at days 7, 10, and 21 when compared with $\mathrm{C} 57 \mathrm{BL} / 6$ mice, but, at day 28 , the level increased significantly (Figure 5F). These data suggest that the absence of $\mathrm{C1q}$ may slow the development of antibody subtypes and affect IgG class switching, which may represent a contributing factor in the decreased clearance of B. burgdorferi observed in $\mathrm{C} 1 \mathrm{q}^{\alpha^{-/}}$mice. However, we cannot exclude the possibility that B cells that express different immunoglobulin isotypes are selectively expanded.

In addition to affecting total antibody development, $\mathrm{C} 1 \mathrm{q}^{-/-}$ mice also developed different subtype populations of $B$. burgdorferispecific antibodies relative to C57BL/6 mice. Here, the level of B. burgdorferi-specific IgM in $\mathrm{C} 1 \mathrm{q}^{-/-}$mice was significantly higher than in $\mathrm{C} 57 \mathrm{BL} / 6$ parent after day 21 and was stably maintained at day 28, whereas the level of IgM in C57BL/6 mice reached the peak at day 21 and then started to decrease at day 28 (Figure 6A), suggesting that the IgG isotype class switching was delayed in $\mathrm{C} 1 \mathrm{q}^{-/-}$mice. Similarly, the level of B. burgdorferispecific IgG1 and IgG3 was higher in $\mathrm{C} 1 \mathrm{q}^{-/-}$mice than $\mathrm{C} 57 \mathrm{BL} / 6$ after day 21 and 28, respectively (Figures 6B,E), whereas the level of $B$. burgdorferi-specific IgG2a and IgG2b are slightly lower in $\mathrm{C} 1 \mathrm{q}^{-/-}$mice when compared with their C57BL/6 parent (Figures 6C,D). However, although $\mathrm{C} 1 \mathrm{q}^{-/-}$mice produced more B. burgdorferi-specific IgM, IgG1, and IgG3, they still harbored higher number of bacteria than $\mathrm{C} 57 \mathrm{BL} / 6$ at these two time points (Figure 1), suggesting that $\mathrm{C} 1 \mathrm{q}$ is essential for clearance by $B$. burgdorferi-specific antibodies, and that the antibodies alone fail to manage borrelial infection.

\section{DISCUSSION}

Borrelia burgdorferi sensu lato isolates exhibit different sensitivities to the various host complement pathways $(21,39,40)$. Despite these differences, it remains controversial whether the complement system controls borrelial infection in vivo, and, specifically, the role of the classical complement pathway in 

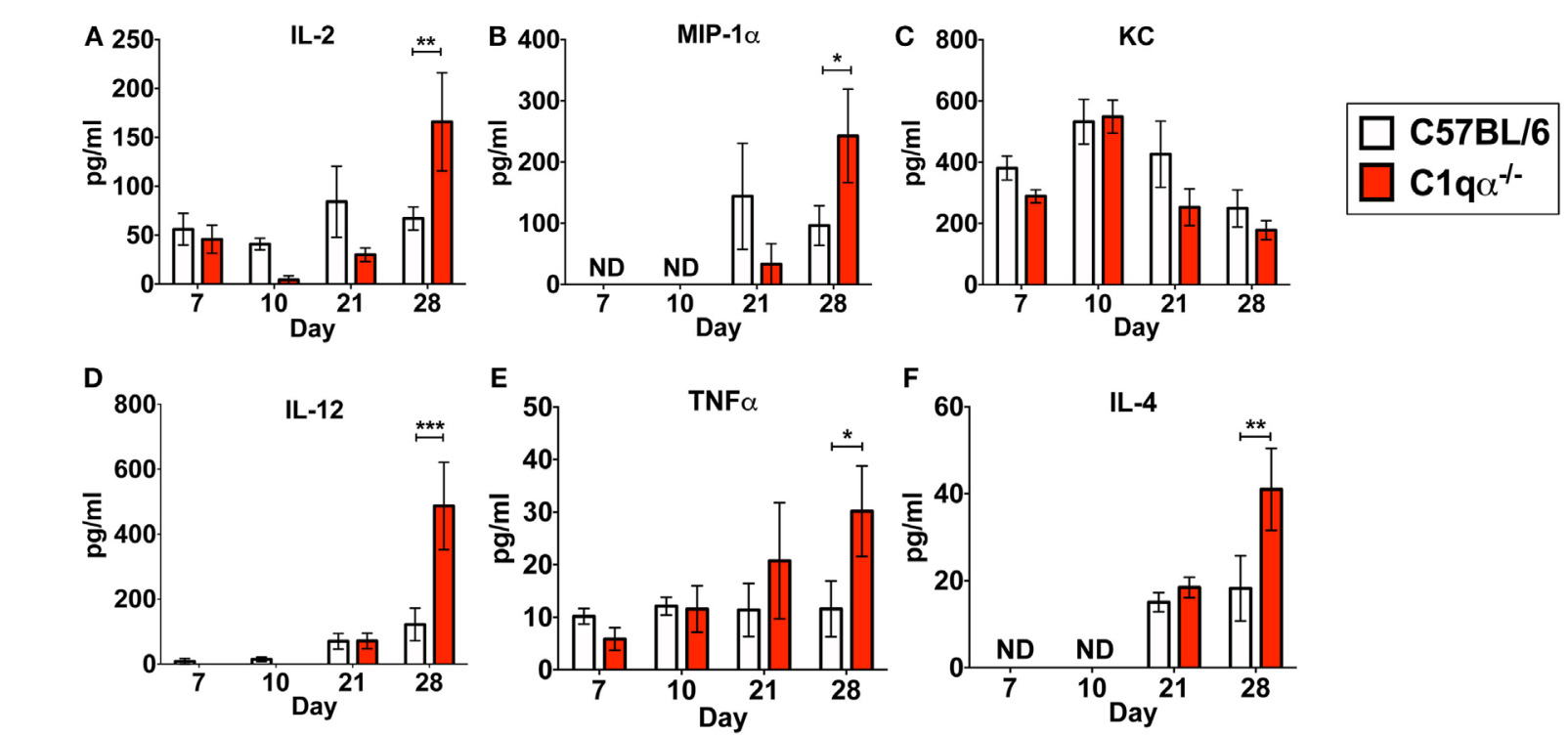

E $50 \quad \quad T N F \alpha$
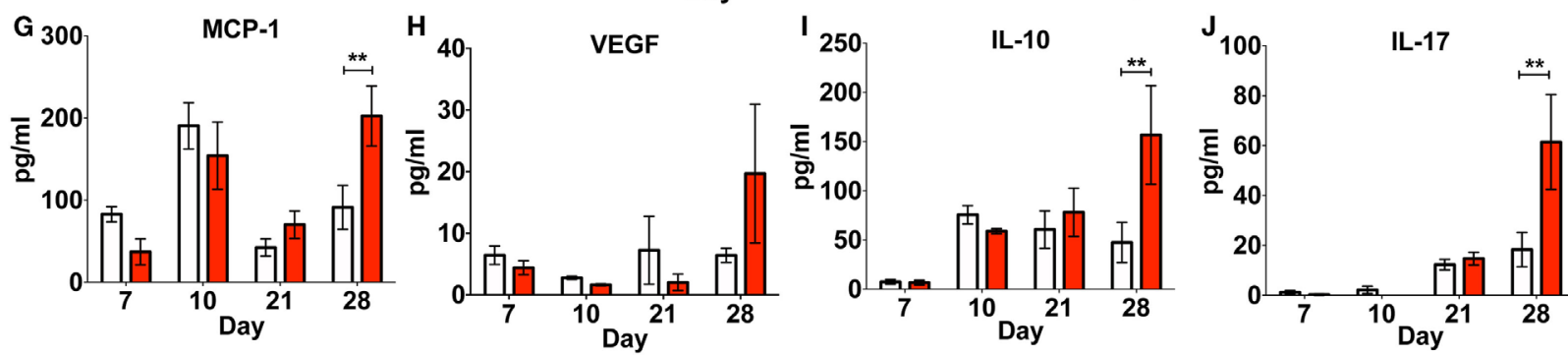

FIGURE 4 | C1q deficiency affects the level of circulating cytokines in infected mice. Whole blood was collected from mice infected with $10^{4}$ Borrelia burgdorferi strain MSK5 (24) at 7, 10, 21, and 28 days post-infection. Serum was isolated by centrifugation, and the level of 10 circulating cytokines (A-J) was determined using the Bio-Plex system employing the Luminex multianalyte profiling technology. The white column represents C57BL/6 mice, whereas the red column refers to data associated with $\mathrm{C} 1 \mathrm{q} \alpha^{-/-}$mice; $n=4-5$ for samples from days 7,10 , and $21 ; n=10$ for samples from day 28 . Abbreviation: ND, not detected ( $P<0.05$; ${ }^{\star \star} P<0.01 ;$ and $\left.{ }^{\star \star \star} P<0.001\right)$.

borrelial clearance is still unclear. In this study, we evaluated the role of the classical complement pathway in the infection of $B$. burgdorferi by comparing the course of infection in mice genetically deficient in complement component $\mathrm{C} 1 \mathrm{q} \alpha$-chain $\left(\mathrm{C} 1 \mathrm{q}^{-/-}\right)$to that of its parent, the $\mathrm{C} 57 \mathrm{BL} / 6$ mouse. Using in vivo imaging, combined with qPCR quantification, we showed that $\mathrm{C} 1 \mathrm{q}^{-/-}$mice harbored more $B$. burgdorferi than the isogenic parent mouse in skin tissues as early as 10 days of infection, and in skin, joint, and heart tissues at later stages of infection (Figures 1 and 3). In addition to limiting B. burgdorferi numbers, the absence of $\mathrm{C} 1 \mathrm{q}$ also results in dysregulation of the Th1/Th2 cytokine and chemokine response that may affect localized tissue inflammation (Figure 4). Furthermore, the lack of $\mathrm{C} 1 \mathrm{q}$ alters the total and borrelial-specific antibody production, which may compromise the adaptive immune response to borrelial infection and result in a higher bacterial burden. Taken together, this study demonstrates critical roles of the classical complement pathway in B. burgdorferi infection, not only to limit borrelial colonization by facilitating antibody killing but to also in its role in altering the development of the adaptive immune response, which may augment tissue inflammation.
Antibodies are an important adaptive immune mechanism used to control infection. In the case of B. burgdorferi, passive transfer of borrelial-specific antibodies quells infectivity, indicating an important role for humoral immunity in borrelial clearance (34-38). In this regard, and within the context of borrelial-specific antibody, both complement-dependent and -independent responses contribute to the clearance of $B$. burgdorferi $(41,42)$. In this study, we found higher bacterial burden in the skin, joint, and heart of $\mathrm{C} 1 \mathrm{q}^{-/-}$mice at 3 weeks post-infection when compared with parent mice, indicating that the presence of C1q limits borrelial load, likely by promoting borrelial-specific antibody-mediated killing. After 4 weeks of infection, the bacterial numbers were similar in the skin tissues of $\mathrm{C} 1 \mathrm{q}^{-/-}$and parent mice, but prominently lower than that in the skin of $\mathrm{C} 1 \mathrm{q}^{-/-}$mice at day 21, suggesting that a C1q-independent antibody response to $B$. burgdorferi limited the infection in skin tissues at this stage. Interestingly, in vivo imaging demonstrated that the colonization of $B$. burgdorferi in both the parent and $\mathrm{C} 1 \mathrm{q} \alpha^{-/-}$mice decreased to a similar level by day 14 , indicating that a C1qindependent antibody against $B$. burgdorferi likely also played a role in reducing borrelial levels at this time point (Figure 2). 

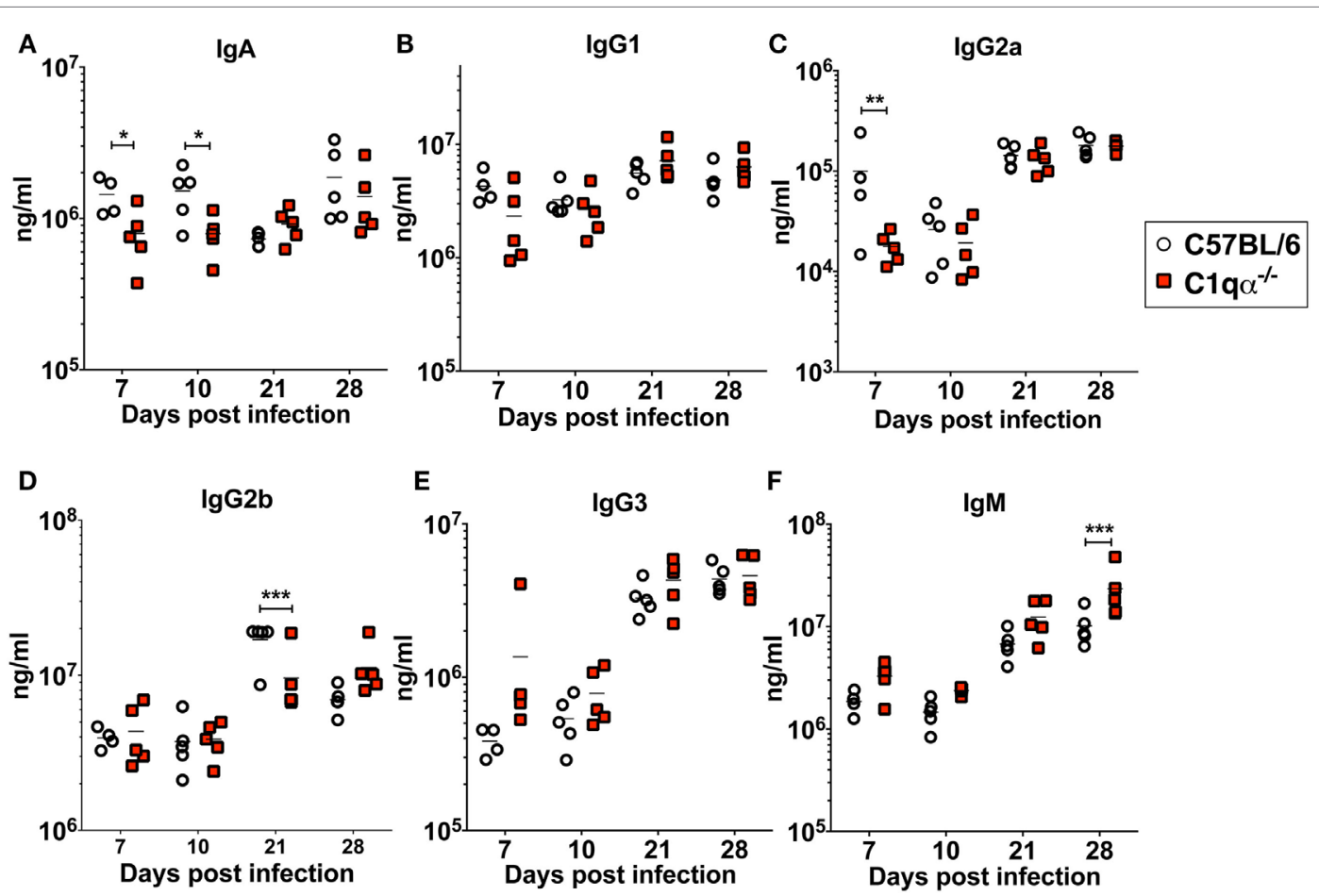

FIGURE 5 | Lack of C1q affects the level of immunoglobulins IgA (A), IgG1 (B), IgG2a (C), IgG2b (D), IgG3 (E), and lgM (F) in infected mice. Whole blood was collected from mice infected with $10^{4}$ Borrelia burgdorferi strain MSK5 (24) at 7, 10, 21, and 28 days post-infection. Serum level of immunoglobulins was determined by the Bio-Plex system employing the Luminex multianalyte profiling technology. White circles refer to samples from C57BL/6 mice, whereas red squares represent data from C1q $\alpha^{-1-}$ mice $\left(n=5 ;{ }^{*} P<0.05 ;{ }^{\star \star} P<0.01\right.$; and $\left.{ }^{* \star} P<0.001\right)$.
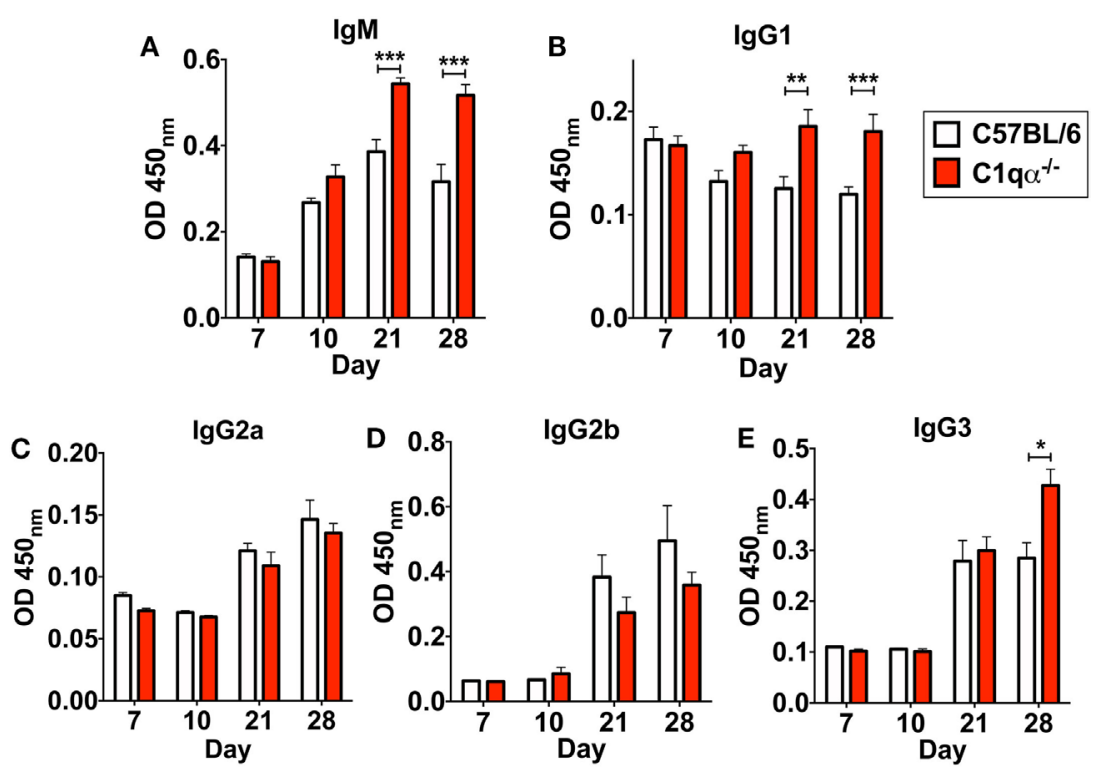

FIGURE 6 | Lack of C1q alters the level of Borrelia-specific antibody subtypes IgM (A), lgG1 (B), IgG2a (C), lgG2b (D), and lgG3 (E) in infected mice. Whole blood was collected from mice infected with $10^{4}$ Borrelia burgdorferi strain MSK5 (24) at 7, 10, 21, and 28 days post-infection. Serum level of Borrelia-specific immunoglobulin subtypes was determined by ELISA using total protein lysate derived from B. burgdorferi strain MSK5. White columns refer to C57BL/6 mice, whereas red columns represent data from $\mathrm{C} 1 \mathrm{q} \alpha^{-/-}$mice $\left(n=5 ;{ }^{\star} P<0.05\right.$; ${ }^{\star \star} P<0.01$; and $\left.{ }^{\star \star \star} P<0.001\right)$. 
Earlier studies showed that borrelial-specific antibodies can be bactericidal in vitro independent of the presence of complement (42, 43). Regarding in vivo studies, Schmitz et al. showed that passive immunization with anti-Borrelia serum in hamsters was abrogated by the depletion of complement (41). However, the complement-dependent protection was only provided by serum taken from hamsters 1 and 10 weeks post-infection, whereas the serum taken at 3 weeks following infection cleared B. burgdorferi independent of complement, presumably due, in part, to borreliacidal antibodies to OspB (42). By contrast, our data showed that the classical pathway decreased the bacterial load at both 10 and 21 days of infection (Figure 3). It is worth noting that the aforementioned study used an inoculum of $10^{6} \mathrm{~B}$. burgdorferi, which is 100-fold higher than the dose used here, and employed a different animal model (41). These differences could explain why the temporal and spatial dynamics of the B. burgdorferi infection and antibody response observed here is not in agreement with the hamster infectivity data. Nevertheless, both studies showed that complement-dependent and -independent antibodies control B. burgdorferi at a different stage of infection. Although the C1qindependent antibody appears to limit B. burgdorferi colonization in the skin by day 28 , our results also show that $\mathrm{C} 1 \mathrm{q}^{-/-}$mice exhibit a significant increase in borrelial burden within both joint and heart tissues, indicating that the C1q-dependent antibody clearance contributes to the control of B. burgdorferi in those tissues (Figure 1B).

Using in vivo imaging and qPCR quantification, we found that $\mathrm{C} 1 \mathrm{q}^{-/-}$mice harbored more bacteria in skin tissue relative to parent mice. It is unlikely that borrelial-specific IgG controls the infection at day 10 or earlier since high titer and high affinity IgG develop only after class switching has occurred. One mechanism that might limit B. burgdorferi expansion early is recognition of naïve and borrelial antigen-specific IgM antibodies, which have a 1,000-fold greater binding affinity to $\mathrm{Clq}$ when compared with $\operatorname{IgG}(44,45)$. Given that borrelial-specific IgM develops early and as prelude to class switching, it is likely that the antigen-specific $\mathrm{IgM}$ also controls borrelial infection in a C1q-dependent manner. This observation is consistent with prior studies demonstrating that IgM limits B. burgdorferi infection. Specifically, Belperron and Bockenstedt found that infected ticks feeding on B-cell-deficient mice $\left(\mathrm{B} 6 \mathrm{Igh}^{-/-}\right)$harbor more spirochetes than those that fed on wild-type mice. Passive transfer of either normal mouse serum or natural mouse IgM into B6Igh ${ }^{-/-}$mice reduced spirochete burden in feeding ticks, whereas naïve IgG antibodies had no effect (45). These observations suggest that IgM is involved in both innate and adaptive immune response following borrelial infection and the data presented herein link $\mathrm{Clq}$ to IgM-mediated clearance. However, IgM may be more efficient in killing B. burgdorferi in the blood during dissemination rather than in the connective tissues where $B$. burgdorferi prefer to colonize, due to the large molecular size of IgM that prevents it from reaching B. burgdorferi in deeper tissues (19). This hypothesis may explain why we failed to detect any difference in borrelial colonization between $\mathrm{C} 1 \mathrm{q}^{-/-}$ and the parent mice before day 10. It is also likely that natural IgM-dependent killing before day 10 is independent of $\mathrm{C} 1 \mathrm{q}$ or that the number of $B$. burgdorferi cleared by natural $\operatorname{IgM}$ is beyond the detection limitation of imaging and qPCR employed here.
Bacterial burden of B. burgdorferi is, in part, controlled by complement mediated, antibody-dependent killing via different mechanisms, including antibody directed killing (42), lysis of bacteria by MAC formation, and phagocytosis of opsonized spirochetes $(46,47)$. During natural infection with B. burgdorferi, phagocytic cells play a critical role in pathogen control at both early and later stages of infection. Phagocytosis of B. burgdorferi by activated macrophages in vitro can occur independent of borrelial antigen-specific antibodies (31). On the other hand, phagocytosis by polymorphonuclear leukocytes is mediated by the borrelial antigen-specific antibodies to opsonize the spirochetes (31). Therefore, the loss of C1q and differences within the immunoglobulin population in $\mathrm{C} 1 \mathrm{q}^{-/-}$mice may lead to decreased phagocytosis by neutrophils, as well as less C1q-dependent MAC formation, which could contribute to the increased bacterial load in those mice. However, since the C57BL/6 parent and $\mathrm{C} 1 \mathrm{q}^{-/-}$ mice did not show differences in bacterial load before day 10 post-infection, we contend that the differences observed are due to $\mathrm{C} 1 \mathrm{q}$-dependent killing mechanisms that require the development of antibodies directed against B. burgdorferi.

$\mathrm{Clq}$ is also known to regulate $\mathrm{T}$ cell development and immune response (47), which is linked to joint inflammation following $B$. burgdorferi infection (48). In this study, we also asked if $\mathrm{Clq}$ deficiency alters the systemic immune response to $B$. burgdorferi infection, by determining the level of cytokines and chemokines in the blood of infected mice at different stages of infection. We found that Th1, Th2, and Th17 associated cytokines were all significantly higher in the $\mathrm{C} 1 \mathrm{q}^{-/-}$mice only following 28 days of infection when compared with the parent mice (Figure 4), whereas the level of cytokines in mock-infected mice were not affected (data not shown). All other time points showed only modest differences (Figure 4). The simultaneous elevation of Th1, Th2, and Th17 associated cytokines was also observed in systemic lupus erythematosus patients, which is associated with C1q deficiency (49-51), suggesting C1q plays a role in balancing $\mathrm{T}$ cell response in tissue inflammation and damage. As indicated earlier, the significant elevation of cytokines/chemokines were only observed in $\mathrm{C} 1 \mathrm{q}^{-/-}$mice infected with $B$. burgdorferi for 28 days, suggesting that the imbalance of $\mathrm{T}$-cell response in $\mathrm{C} 1 \mathrm{q}^{-/-}$mice involves a cell-mediated response to borrelial infection. It has been shown that $\mathrm{C} 1 \mathrm{q}$ bound to apoptotic cells suppresses human macrophage and dendritic cell-mediated Th1 and Th17 T cell subset proliferation (52), which could explain why the lack of $\mathrm{C} 1 \mathrm{q}$ fails to limit Th1 and Th17 response to borrelial infection, given that $B$. burgdorferi infection is purported to induce apoptosis in monocytes (53). However, it is still not clear why the Th2 response was elevated. One possibility is that inflammation mediated by Th1 and Th17 subtype also triggers stimulation of the Th2 response. It is also possible that the higher level of IL-10 produced in infected $\mathrm{Clq}^{-/-}$mice (Figure 4) stimulates anti-inflammatory Th2 response and protects $B$. burgdorferi from elimination, given that borrelial-specific IL-10 production is known to repress spirochete clearance $(54,55)$.

It is well established that the classical pathway is involved in antibody-dependent clearance of pathogens. In this study, we showed that $\mathrm{C} 1 \mathrm{q}^{-/-}$mice harbored more B. burgdorferi both 21 and 28 days post-infection. One likely explanation for 
this observation is that the complement-mediated, antibodydependent killing of B. burgdorferi is reduced in the $\mathrm{C} 1 \mathrm{q}^{-/-}$mice, leading to the retention of greater numbers of the spirochetes (Figure 1). It is also possible that $\mathrm{C} 1 \mathrm{q}$ deficiency compromises the development of both the primary and secondary antibody response, which could diminish B. burgdorferi clearance (56). To test this possibility, we quantified levels of six immunoglobulin sub-classes following borrelial infection and found that the total amount of $\operatorname{IgA}, \operatorname{IgG} 2 \mathrm{a}$, and $\operatorname{IgG} 2 \mathrm{~b}$ are reduced in $\mathrm{C} 1 \mathrm{q} \alpha^{-/-}$mice when compared with the parent strain, while IgM levels are higher in $\mathrm{C} 1 \mathrm{q}^{-/-}$mice. In this regard, C1q deficiency not only compromises antibody killing, but appears to impair antibody production during the infection, both of which contribute to reduced $B$. burgdorferi antibody-mediated clearance. One additional explanation posits that the loss of $\mathrm{C} 1 \mathrm{q}$ leads to decreased C4b deposition on follicular dendritic cells, which may cause premature collapse of germinal center response, due to diminished antigen presentation by the dendritic cells to B cells within the germinal center (20). In fact, B. burgdorferi infection leads to strong and sustained IgM response and delayed development of long-lived antibody and B cell memory $(19,20)$, perhaps due to abrogated $\mathrm{C} 4 \mathrm{~b}$ deposition.

In addition to the total antibody level, the level of B. burgdorferispecific IgM, IgG1, and IgG3 are increased in C1q $\alpha^{-/-}$mice relative to $\mathrm{C} 57 \mathrm{BL} / 6$ parent, while IgG2a and IgG2b are not affected or mildly decreased (Figure 6). The increased level of Borreliaspecific IgM in $\mathrm{C} 1 \mathrm{q}^{-/-}$mice parallels with the observations of altered B cell response during B. burgdorferi infection such that serum IgM levels remain high and the ratio of $\operatorname{IgG}$ and IgM is relatively constant $(47,57)$. These data suggest that the dampened $\mathrm{B}$ cell response during borrelial infection could be due to the delayed activation of the classical complement pathway. In fact, B. burgdorferi interferes with the activation of the classical pathway via surface proteins, such as BBK32 and OspC $(22,23,58)$. Furthermore, interference of the classical pathway activation could also contribute to B. burgdorferi persistence in immunocompetent hosts with the presence of borrelial-specific antibody. In addition to IgM, the level of IgG1 and IgG3 are also higher in $\mathrm{C} 1 \mathrm{q}^{-1-}$ mice. These three isotypes all bind to $\mathrm{C} 1 \mathrm{q}$ and activate the classical pathway, whereas IgG2a and IgG2b bind to the Fc receptor (56). As such, it is likely that those immuno-complexes formed with C1q-binding antibodies cannot be opsonized by the complement system during infection due to the absence of $\mathrm{C} 1 \mathrm{q}$,

\section{REFERENCES}

1. Hinckley AF, Connally NP, Meek JI, Johnson BJ, Kemperman MM, Feldman KA, et al. Lyme disease testing by large commercial laboratories in the United States. Clin Infect Dis (2014) 59:676-81. doi:10.1093/cid/ciu397

2. Duray PH, Steere AC. Clinical pathologic correlations of Lyme disease by stage. Ann N Y Acad Sci (1988) 539:65-79. doi:10.1111/j.1749-6632.1988. tb31839.x

3. Shapiro ED. Lyme disease. N Engl J Med (2014) 370:1724-31. doi:10.1056/ NEJMcp1314325

4. Steere AC. Lyme disease. N Engl J Med (2001) 345:115-25. doi:10.1056/ NEJM200107123450207

5. Steere AC, Coburn J, Glickstein L. The emergence of Lyme disease. J Clin Invest (2004) 113:1093-101. doi:10.1172/JCI21681 thus fail to be engulfed by phagocytes and accumulated within the circulation system.

In summary, we demonstrate here that the classical complement pathway controls B. burgdorferi infection in vivo, in part by facilitating borrelial-specific antibody-dependent killing of the bacteria. In addition, we find that both complement-dependent and independent antibody killing play a role in limiting $B$. burgdorferi numbers at different stages of infection. Our study also demonstrates that $\mathrm{C} 1 \mathrm{q}$ affects the cytokine production related to both $\mathrm{T}$ cell and $\mathrm{B}$ cell responses in borrelial infection, both of which could control borrelial burden and resolve tissue inflammation. Further studies are warranted to investigate whether other borrelial proteins interact with $\mathrm{C} 1 \mathrm{q}$ to determine whether B. burgdorferi employs additional strategies to neutralize the classical complement pathway to promote survival in the mammalian hosts they infect.

\section{ETHICS STATEMENT}

All animal experiments were performed in accordance to the Association for Assessment and Accreditation of Laboratory Animal Care (AAALAC) guidelines. The Texas A\&M University Institutional Animal Care and Use Committee (IACUC) reviewed and approved all animal procedures/protocols used in this study.

\section{AUTHOR CONTRIBUTIONS}

$\mathrm{HZ}$ and JS outlined the research plan and wrote the manuscript. $\mathrm{HZ}$, JX, and JS conducted the experimentation and evaluated the data obtained.

\section{ACKNOWLEDGMENTS}

We thank Yi Xu, Texas A\&M Health Science Center, Houston, TX, USA, for providing the $\mathrm{C} 1 \mathrm{q}^{-/-}$mice and to Brandon Garcia for critical reading of the manuscript and helpful comments. We acknowledge Magnus Höök for providing support and insight into this report and Ms. Jean Kovar for assisting in the breeding of the C1q knockout mice. We are grateful to Caleb Grimes for excellent technical assistance. This work was supported by Public Health Service Grants AI058086 and AI119821 from the NIH/ NIAID (to JS).

6. Carroll MC. The complement system in regulation of adaptive immunity. Nat Immunol (2004) 5:981-6. doi:10.1038/ni1113

7. Charles A, Janeway J, Travers P, Walport M, Shlomchik MJ. The complement system and innate immunity. 5th ed. Immunobiology: The Immune System in Health and Disease. New York: Garland Science (2001). p. 43-64.

8. Dunkelberger JR, Song W-C. Complement and its role in innate and adaptive immune responses. Cell Res (2010) 20:34-50. doi:10.1038/cr. 2009.139

9. Kemper C, Atkinson JP. T-cell regulation: with complements from innate immunity. Nat Rev Immunol (2007) 7:9-18. doi:10.1038/nri1994

10. Bexborn F, Andersson PO, Chen H, Nilsson B, Ekdahl KN. The tick-over theory revisited: formation and regulation of the soluble alternative complement C3 convertase (C3(H2O)Bb). Mol Immunol (2008) 45:2370-9. doi:10.1016/j. molimm.2007.11.003 
11. Pangburn MK, Müller-Eberhard HJ. Initiation of the alternative complement pathway due to spontaneous hydrolysis of the thioester of C3. Ann N Y Acad Sci (1983) 421:291-8. doi:10.1111/j.1749-6632.1983.tb18116.x

12. Garcia BL, Zwarthoff SA, Rooijakkers SHM, Geisbrecht BV. Novel evasion mechanisms of the classical complement pathway. JImmunol (2016) 197:2051-60. doi:10.4049/jimmunol.1600863

13. Wallis R, Mitchell DA, Schmid R, Schwaeble WJ, Keeble AH. Paths reunited: initiation of the classical and lectin pathways of complement activation. Immunobiology (2010) 215:1-11. doi:10.1016/j.imbio.2009.08.006

14. Thielens NM, Tedesco F, Bohlson SS, Gaboriaud C, Tenner AJ. C1q: a fresh look upon an old molecule. Mol Immunol (2017) 89:73-83. doi:10.1016/j. molimm.2017.05.025

15. Bobak DA, Gaither TA, Frank MM, Tenner AJ. Modulation of FcR function by complement: subcomponent $\mathrm{Clq}$ enhances the phagocytosis of IgGopsonized targets by human monocytes and culture-derived macrophages. J Immunol (1987) 138:1150-6.

16. Bohlson SS, O'Conner SD, Hulsebus HJ, Ho M-M, Fraser DA. Complement, $\mathrm{clq}$, and clq-related molecules regulate macrophage polarization. Front Immunol (2014) 5:402. doi:10.3389/fimmu.2014.00402

17. Benoit ME, Clarke EV, Morgado P, Fraser DA, Tenner AJ. Complement protein $\mathrm{Clq}$ directs macrophage polarization and limits inflammasome activity during the uptake of apoptotic cells. J Immunol (2012) 188:5682-93. doi:10.4049/jimmunol.1103760

18. Clarke EV, Tenner AJ. Complement modulation of $\mathrm{T}$ cell immune responses during homeostasis and disease. JLeukoc Biol (2014) 96:745-56. doi:10.1189/ jlb.3MR0214-109R

19. Hastey CJ, Elsner RA, Barthold SW, Baumgarth N. Delays and diversions mark the development of B cell responses to Borrelia burgdorferi infection. J Immunol (2012) 188:5612-22. doi:10.4049/jimmunol.1103735

20. Elsner RA, Hastey CJ, Olsen KJ, Baumgarth N. Suppression of long-lived humoral immunity following Borrelia burgdorferi infection. PLoS Pathog (2015) 11:e1004976. doi:10.1371/journal.ppat.1004976

21. van Dam AP, Oei A, Jaspars R, Fijen C, Wilske B, Spanjaard L, et al. Complement-mediated serum sensitivity among spirochetes that cause Lyme disease. Infect Immun (1997) 65:1228-36.

22. Caine JA, Lin Y-P, Kessler JR, Sato H, Leong JM, Coburn J. Borrelia burgdorferi outer surface protein $\mathrm{C}(\mathrm{OspC})$ binds complement component $\mathrm{C} 4 \mathrm{~b}$ and confers bloodstream survival. Cell Microbiol (2017) 19:e12786. doi:10.1111/ cmi. 12786

23. Garcia BL, Zhi H, Wager B, Höök M, Skare JT. Borrelia burgdorferi BBK32 inhibits the classical pathway by blocking activation of the $\mathrm{C} 1$ complement complex. PLoS Pathog (2016) 12:e1005404. doi:10.1371/journal.ppat.1005404

24. Labandeira-Rey M, Skare JT. Decreased infectivity in Borrelia burgdorferi strain B31 is associated with loss of linear plasmid 25 or 28-1. Infect Immun (2001) 69:446-55. doi:10.1128/IAI.69.1.446-455.2001

25. Hyde JA, Weening EH, Chang M, Trzeciakowski JP, Höök M, Cirillo JD, et al. Bioluminescent imaging of Borrelia burgdorferi in vivo demonstrates that the fibronectin-binding protein BBK32 is required for optimal infectivity. Mol Microbiol (2011) 82:99-113. doi:10.1111/j.1365-2958.2011.07801.x

26. Botto M. C1q knock-out mice for the study of complement deficiency in autoimmune disease. Exp Clin Immunogenet (1998) 15:231-4. doi:10.1159/ 000019076

27. Hyde JA, Shaw DK, Smith R III, Trzeciakowski JP, Skare JT. The BosR regulatory protein of Borrelia burgdorferi interfaces with the RpoS regulatory pathway and modulates both the oxidative stress response and pathogenic properties of the Lyme disease spirochete. Mol Microbiol (2009) 74:1344-55. doi:10.1111/j.1365-2958.2009.06951.x

28. Weening EH, Parveen N, Trzeciakowski JP, Leong JM, Höök M, Skare JT. Borrelia burgdorferi lacking DbpBA exhibits an early survival defect during experimental infection. Infect Immun (2008) 76:5694-705. doi:10.1128/ IAI.00690-08

29. Liveris D, Wang G, Girao G, Byrne DW, Nowakowski J, McKenna D, et al. Quantitative detection of Borrelia burgdorferi in 2-millimeter skin samples of erythema migrans lesions: correlation of results with clinical and laboratory findings. J Clin Microbiol (2002) 40:1249-53. doi:10.1128/ JCM.40.4.1249-1253.2002

30. Pal U, Wang P, Bao F, Yang X, Samanta S, Schoen R, et al. Borrelia burgdorferi basic membrane proteins A and B participate in the genesis of Lyme arthritis. J Exp Med (2008) 205:133-41. doi:10.1084/jem.20070962
31. Montgomery RR, Lusitani D, de Boisfleury Chevance A, Malawista SE. Human phagocytic cells in the early innate immune response to Borrelia burgdorferi. J Infect Dis (2002) 185:1773-9. doi:10.1086/340826

32. Son M, Diamond B, Santiago-Schwarz F. Fundamental role of C1q in autoimmunity and inflammation. Immunol Res (2015) 63:101-6. doi:10.1007/ s12026-015-8705-6

33. Kouser L, Madhukaran SP, Shastri A, Saraon A, Ferluga J, Al-Mozaini M, et al. Emerging and novel functions of complement protein C1q. Front Immunol (2015) 6:317. doi:10.3389/fimmu.2015.00317

34. Barthold SW, Bockenstedt LK. Passive immunizing activity of sera from mice infected with Borrelia burgdorferi. Infect Immun (1993) 61:4696-702.

35. Barthold SW, deSouza M, Feng S. Serum-mediated resolution of Lyme arthritis in mice. Lab Invest (1996) 74:57-67.

36. Barthold SW, Feng S, Bockenstedt LK, Fikrig E, Feen K. Protective and arthritis-resolving activity in sera of mice infected with Borrelia burgdorferi. Clin Infect Dis (1997) 25(Suppl 1):S9-17. doi:10.1086/516166

37. Bockenstedt LK, Shanafelt MC, Belperron A, Mao J, Barthold SW. Humoral immunity reflects altered $\mathrm{T}$ helper cell bias in Borrelia burgdorferi-infected gamma delta T-cell-deficient mice. Infect Immun (2003) 71:2938-40. doi:10.1128/IAI.71.5.2938-2940.2003

38. Fikrig E, Bockenstedt LK, Barthold SW, Chen M, Tao H, Ali-Salaam P, et al. Sera from patients with chronic Lyme disease protect mice from Lyme borreliosis. J Infect Dis (1994) 169:568-74. doi:10.1093/infdis/169.3.568

39. Kochi SK, Johnson RC. Role of immunoglobulin G in killing of Borrelia burgdorferi by the classical complement pathway. Infect Immun (1988) 56:314-21.

40. Breitner-Ruddock S, Würzner R, Schulze J, Brade V. Heterogeneity in the complement-dependent bacteriolysis within the species of Borrelia burgdorferi. Med Microbiol Immunol (1997) 185:253-60. doi:10.1007/s004300050038

41. Schmitz JL, Lovrich SD, Callister SM, Schell RF. Depletion of complement and effects on passive transfer of resistance to infection with Borrelia burgdorferi. Infect Immun (1991) 59:3815-8.

42. LaRocca TJ, Holthausen DJ, Hsieh C, Renken C, Mannella CA, Benach JL. The bactericidal effect of a complement-independent antibody is osmolytic and specific to Borrelia. Proc Natl Acad Sci U S A (2009) 106:10752-7. doi:10.1073/ pnas. 0901858106

43. Katona LI, Ayalew S, Coleman JL, Benach JL. A bactericidal monoclonal antibody elicits a change in its antigen, OspB of Borrelia burgdorferi, that can be detected by limited proteolysis. J Immunol (2000) 164:1425-31. doi:10.4049/ jimmunol.164.3.1425

44. Ochsenbein AF, Zinkernagel RM. Natural antibodies and complement link innate and acquired immunity. Immunol Today (2000) 21:624-30. doi:10.1016/ S0167-5699(00)01754-0

45. Belperron AA, Bockenstedt LK. Natural antibody affects survival of the spirochete Borrelia burgdorferi within feeding ticks. Infect Immun (2001) 69:6456-62. doi:10.1128/IAI.69.10.6456-6462.2001

46. Kraiczy P. Hide and seek: how Lyme disease spirochetes overcome complement attack. Front Immunol (2016) 7:385. doi:10.3389/fimmu.2016.00385

47. Tracy KE, Baumgarth N. Borrelia burgdorferi manipulates innate and adaptive immunity to establish persistence in rodent reservoir hosts. Front Immunol (2017) 8:116. doi:10.3389/fimmu.2017.00116

48. McKisic MD, Redmond WL, Barthold SW. Cutting edge: T cell-mediated pathology in murine Lyme borreliosis. JImmunol (2000) 164:6096-9. doi:10.4049/jimmunol.164.12.6096

49. van Schaarenburg RA, Magro-Checa C, Bakker JA, Teng YKO, Bajema IM, Huizinga TW, et al. C1q deficiency and neuropsychiatric systemic lupus erythematosus. Front Immunol (2016) 7:647. doi:10.3389/fimmu.2016.00647

50. Talaat RM, Mohamed SF, Bassyouni IH, Raouf AA. Th1/Th2/Th17/Treg cytokine imbalance in systemic lupus erythematosus (SLE) patients: correlation with disease activity. Cytokine (2015) 72:146-53. doi:10.1016/j.cyto. 2014.12.027

51. Wong CK, Ho CY, Li EK, Lam CW. Elevation of proinflammatory cytokine (IL-18, IL-17, IL-12) and Th2 cytokine (IL-4) concentrations in patients with systemic lupus erythematosus. Lupus (2000) 9:589-93. doi:10.1191/096120300678828703

52. Clarke EV, Weist BM, Walsh CM, Tenner AJ. Complement protein C1q bound to apoptotic cells suppresses human macrophage and dendritic cell-mediated Th17 and Th1 T cell subset proliferation. J Leukoc Biol (2015) 97:147-60. doi:10.1189/jlb.3A0614-278R 
53. Ramesh G, Santana-Gould L, Inglis FM, England JD, Philipp MT. The Lyme disease spirochete Borrelia burgdorferi induces inflammation and apoptosis in cells from dorsal root ganglia. J Neuroinflammation (2013) 10:865. doi:10.1186/ 1742-2094-10-88

54. Lazarus JJ, Meadows MJ, Lintner RE, Wooten RM. IL-10 deficiency promotes increased Borrelia burgdorferi clearance predominantly through enhanced innate immune responses. JImmunol (2006) 177:7076-85. doi:10.4049/ jimmunol.177.10.7076

55. Sonderegger FL, Ma Y, Maylor-Hagan H, Brewster J, Huang X, Spangrude GJ, et al. Localized production of IL-10 suppresses early inflammatory cell infiltration and subsequent development of IFN- $\gamma$-mediated Lyme arthritis. J Immunol (2012) 188:1381-93. doi:10.4049/jimmunol.1102359

56. Sörman A, Zhang L, Ding Z, Heyman B. How antibodies use complement to regulate antibody responses. Mol Immunol (2014) 61:79-88. doi:10.1016/ j.molimm.2014.06.010

57. Tunev SS, Hastey CJ, Hodzic E, Feng S, Barthold SW, Baumgarth N. Lymphoadenopathy during Lyme borreliosis is caused by spirochete migration-induced specific B cell activation. PLoS Pathog (2011) 7:e1002066. doi:10.1371/journal.ppat.1002066

58. Pietikäinen J, Meri T, Blom AM, Meri S. Binding of the complement inhibitor C4b-binding protein to Lyme disease borreliae. Mol Immunol (2010) 47:1299-305. doi:10.1016/j.molimm.2009.11.028

Conflict of Interest Statement: The authors declare that the research was conducted in the absence of any commercial or financial relationships that could be construed as a potential conflict of interest.

Copyright (c) 2018 Zhi, Xie and Skare. This is an open-access article distributed under the terms of the Creative Commons Attribution License (CC BY). The use, distribution or reproduction in other forums is permitted, provided the original author(s) and the copyright owner are credited and that the original publication in this journal is cited, in accordance with accepted academic practice. No use, distribution or reproduction is permitted which does not comply with these terms. 